\title{
THE PROCESS OF TRANSITION AND THE CAPITAL MARKET IN THE REPUBLIC OF CROATIA
}

\author{
Branimir Marković, Professor \\ Branko Matić, Professor \\ Faculty of Economics in Osijek
}

\section{Summary}

As a transition country, Croatia is confronted with fundamental changes in the segment of capital transactions. These changes are the result of the country's market orientation, of its position in the globalization (integration) processes, but especially of its needs.

The limiting framework of a more significant development of the capital market is set by the reached level of development of the Croatian economy, by the underdevelopment of the entire financial market, by, until recently, inadequate legal regulation and, partially, by the specific tradition and conservatism in this segment.

The present situation in the segment of capital transactions indicates the comprehensiveness of the changes regarding the development of the capital market, but at the same time the extreme sensitivity of this market to changes of the economic activity in the country, as well as in its surrounding, and high sensibility relating to the political decision about the initiation of negotiations with the European Union concerning the membership of Croatia in this association.

Key words: financial system, capital market, transition, the European Union

\section{Introduction}

The changes in the financial sector, especially in the segment of capital transactions, in the Republic of Croatia are very explicit. The frameworks for these changes are set by: the condition of the economy, the level of the market openness, the size of the Croatian market, the development of other segments of the financial system, by legal regulation, but also by political requirements relating to the beginning of aaccession negotiations between the Republic of Croatia and the European Union $(\mathrm{EU})^{1}$. Precisely this fact indicates the extreme importance of stability, but also of membership in such an association. The reasons for this are the standards that apply to all member states, resulting in the safety for investors.

${ }^{1}$ The Republic of Croatia has been a candidate for membership in the EU since $18^{\text {th }}$ June 2004 . 


\section{Capital Market in the Republic of Croatia}

Croatian capital market, as a part of the financial system, is determined by the types and number of financial instruments used to trade on the market, by institutional frameworks and by legal regulation. In spite of its specific characteristics, capital market can not be considered as separate and isolated. The reason for this lies in the fact that all financial markets are connected through binding factors - credit, the existence of speculation and arbitration, as well as perfection and efficiency of the market (Novak, 1999:19); these circumstances must therefore necessarily be accepted.

\subsection{Financial Instruments on the Capital Market in the Republic of Croatia}

In business operations in which financial instruments have the date of expiry longer than one year, we speak of long-term financial instruments, and these are trade objects on the capital market. In the Republic of Croatia, practically all "classical" financial institutions: deposit, contracting (insurance companies and pension funds) and investment institutions can participate on the capital market (Novak, 1999:38).

Long-term financial property can usually be classified into two categories:

- equity securities

- debt securities

\subsubsection{Equity Securities Market}

Equity securities market in the Republic of Croatia consists of the purchase and sales of securities through the stock exchange. In Croatia there are two stock exchanges - the Zagreb Stock Exchange and the Varaždin Stock Exchange.

At the end of 2004, the Zagreb Stock Exchange had 183 shares of stock and 153 of those were actively traded with. On this stock exchange, transactions were made on three markets: on the official market, on the public limited companies market, and on the parallel market.

In terms of the turnover volume on this stock exchange, most dominant were the shares of a business conglomerate largely dealing in the production of tobacco products, shares of food processing, pharmaceutical and tourist industry, and shares of insurance companies and banks.

Market capitalization of stock ${ }^{2}$ in 2004 was $30.4 \%$ of the estimated of the gross domestic product (GDP) for that year.

\footnotetext{
${ }^{2}$ Market capitalization of stock consists of the close price of each share multiplied by the number of issued shares and corrected by the share's solvency.
} 
Trading on the Varaždin Stock Exchange includes transactions in five market segments: in the First Quotation, in the Second Quotation, in the Public Companies Quotation, in the Business Investment Funds Quotation and in the Free Market Quotation.

The Varaždin Stock Exchange is specific for its trading in the segment of rights $^{3}$ of the Ministry of Finances and of the former Ministry of Public Works, Reconstruction and Building.

The size and solvency of the Croatian stock market is similar to the trends on the stock markets of most new EU member countries that have joined the Union in 2004 - Table 1. (Croatian National Bank, Annual Report for 2004 - working version: 65-68).

Table 1. Comparison of Capital Market Indicators

\begin{tabular}{|l|r|r|r|r|r|r|}
\hline December 2004 & Bratislava & Budapest & Ljubljana & Prague & Warsaw & Zagreb \\
\hline Average daily transactions, shares & & & & & & \\
(Mill. EUR) & 0.4 & 40.8 & 5.7 & 69.4 & 149.0 & 2.3 \\
$\begin{array}{l}\text { Average daily transactions, bonds } \\
\text { (Mill. EUR) }\end{array}$ & 59.7 & 10.0 & 2.8 & 72.2 & 6.4 & 21.0 \\
Turnover*/GDP***, annual level (\%) & 0.3 & 14.6 & 6.2 & 23.1 & 22.0 & 2.4 \\
Turnover*/GDP***, annual level (\%) & 42.2 & 3.6 & 3.0 & 24.1 & 0.9 & 22.0 \\
Turnover velocity*** & 2.1 & 48.8 & 21,1 & 54.6 & 78.3 & 7.4 \\
$\begin{array}{l}\text { Market capitalization* (Mill. EUR), } \\
\text { end of the month }\end{array}$ & 3,615 & 22,070 & 7,115 & 32,029 & 52,541 & 8,048 \\
$\begin{array}{l}\text { Market capitalization** (Mill. EUR), } \\
\text { end of the month }\end{array}$ & 9,339 & 33,820 & 4,616 & 18,941 & n.a. & 3,202 \\
$\begin{array}{l}\text { Market capitalization*/GDP***, end } \\
\text { of the month (\%) }\end{array}$ & 12.5 & 29.9 & 29.3 & 42.3 & 28.1 & 31.9 \\
$\begin{array}{l}\text { Market capitalization**/GDP***, } \\
\text { end of the month (\%) }\end{array}$ & 32.4 & 45.8 & 19.0 & 25.0 & n.a. & 12.7 \\
$\begin{array}{l}\text { Changes in the Index of shares since } \\
\text { the beginning of the year (\%) }\end{array}$ & 83.9 & 57.2 & 24.7 & 56.6 & 27.9 & 32.1 \\
$\begin{array}{l}\text { Changes in the Index of shares since } \\
\text { the beginning of the month (\%) }\end{array}$ & 8.2 & 3.9 & 1.4 & 2.1 & 4.8 & -2.2 \\
\hline
\end{tabular}

* shares; ** bonds; *** 2003

$* * * *$ analyzing the monthly turnover of shares $* 100$ /market capitalization of share

Source: Reports from the BSSE, BSE, PSE, LJSE, WSE, Zagreb Stock Exchange and FIBV Statistics (www.fibv.org)

${ }^{3}$ These rights are in fact securities by which their holders acquire the right to get shares from the portfolio of the Croatian Privatization fund. 


\subsubsection{Debt Securities Market}

Debt securities market in Croatia gives an excellent illustration of the connection between the fiscal policy and the market itself. Thus the state, following the directives of the fiscal policy, incurs debts on the home capital market by issuing bonds. Also, for the first time in Croatia, local government and self-government in two towns (Koprivnica and Zadar) have issued bonds for the purpose of securing new funding sources.

On the Croatian debt securities market there are state, corporate and municipal bonds, as well as the bonds of the State Agency for Insurance of Savings Deposits and Bank Rehabilitation and the bonds of the Croatian Bank for Reconstruction and Development - Table 2.

Table 2. Bond Issues on the Home Market at the End of February of 2005

\begin{tabular}{|c|c|c|c|c|c|c|c|c|}
\hline Symbol & Issuer & $\begin{array}{l}\text { Date of } \\
\text { Issue }\end{array}$ & Expiration & $\begin{array}{l}\text { Cur- } \\
\text { rency }\end{array}$ & $\begin{array}{l}\text { Face value } \\
\text { of the issue }\end{array}$ & $\begin{array}{l}\text { Nominal } \\
\text { Interest } \\
\text { rate }\end{array}$ & $\begin{array}{l}\text { Close } \\
\text { price* }\end{array}$ & $\begin{array}{c}\text { Current } \\
\text { yield } \\
\text { Feb. 28 } \\
2005\end{array}$ \\
\hline DAB-05CA & $\begin{array}{l}\text { Savings Deposits } \\
\text { Insurance Agency }\end{array}$ & $19 / 12 / 2000$ & $19 / 12 / 2005$ & EUR & $225,000,000$ & $8.375 \%$ & 104,80 & $7.991 \%$ \\
\hline RHMF-O-O8CA & Republic of Croatia & $14 / 12 / 2001$ & $14 / 12 / 2008$ & EUR & $200,000,000$ & $6.875 \%$ & 111.35 & $6.174 \%$ \\
\hline RHMF-O-125A & Republic of Croatia & $23 / 05 / 2002$ & $23 / 05 / 2012$ & EUR & $500,000,000$ & $6.875 \%$ & 115.80 & $5.937 \%$ \\
\hline RHMF-O-085A & Republic of Croatia & $28 / 05 / 2003$ & $26 / 05 / 2008$ & HRK & $1,000,000,000$ & $6.125 \%$ & 100.90 & $6.070 \%$ \\
\hline RHMF-O-142A & Republic of Croatia & $10 / 02 / 2004$ & $10 / 02 / 2014$ & EUR & $650,000,000$ & $5.500 \%$ & 108.00 & $5.093 \%$ \\
\hline RHMF-O-077A & Republic of Croatia & $07 / 07 / 2004$ & $07 / 07 / 2007$ & EUR & $400,000,000$ & $3.875 \%$ & 101.55 & $3.816 \%$ \\
\hline RHMF-O-198A & Republic of Croatia & $29 / 11 / 2004$ & $29 / 11 / 2019$ & EUR & $200,000,000$ & $5.375 \%$ & 105.45 & $5.097 \%$ \\
\hline GDKC-O-116A & $\begin{array}{l}\text { The Town of } \\
\text { Koprivnica }\end{array}$ & $29 / 06 / 2004$ & $29 / 06 / 2011$ & HRK & $60,000,000$ & $6.500 \%$ & - & - \\
\hline GDZD-O-119A & $\begin{array}{l}\text { The Town of } \\
\text { Zadar }\end{array}$ & $01 / 09 / 2004$ & 01/09/2011 & EUR & $18,500,000$ & $5.500 \%$ & - & - \\
\hline HBOR-O-112A & $\begin{array}{l}\text { Croatian Bank for } \\
\text { Reconstruction and } \\
\text { Development }\end{array}$ & $11 / 02 / 2004$ & $11 / 02 / 2011$ & EUR & $300,000,000$ & $4.875 \%$ & - & - \\
\hline BLSC-O-091A & Belišće Co. & $14 / 01 / 2005$ & $14 / 01 / 2009$ & EUR & $8,000,000$ & $5.500 \%$ & - & - \\
\hline HYBA-O-086A & $\begin{array}{l}\text { Hypo-Alpe.Adria } \\
\text { Bank }\end{array}$ & $06 / 06 / 2003$ & $06 / 06 / 2008$ & HRK & $150,000,000$ & $6.500 \%$ & 100.90 & $6.442 \%$ \\
\hline BNAI-O-22CA & Bina Istra Co. & $15 / 12 / 2002$ & $15 / 12 / 2002$ & EUR & $210,000,000$ & $8.000 \%$ & - & - \\
\hline PODR-O-072A & Podravka Co. & $20 / 02 / 2004$ & $20 / 02 / 2007$ & EUR & $27,000,000$ & $5.000 \%$ & - & - \\
\hline AGRK-O-074A & Agrokor Co. & $03 / 04 / 2002$ & $03 / 04 / 2007$ & EUR & $230,000,000$ & $11.000 \%$ & 108.10 & $10.176 \%$ \\
\hline PLVA-O-115A & Pliva Co. & $12 / 05 / 2004$ & $12 / 05 / 2011$ & EUR & $75,000,000$ & $5.750 \%$ & 99.65 & $5.770 \%$ \\
\hline ATGR-O-077A & Atlantic Grupe Ltd. & $15 / 07 / 2004$ & $15 / 07 / 2007$ & EUR & $15,000,000$ & $5.750 \%$ & - & - \\
\hline
\end{tabular}

* in regular exchange

Source: Zagreb Stock Exchange, Monthly Report for February 2005 
The coupon interest rate ranges between 3.875 and $11 \%$. Most of the bonds are denominated in Euros.

From the point of view of solvency, government bonds are on the top of the list, whereas corporate bonds are the least solvent.

Total market capitalization on the home market by the end of 2004 amounted to $14.9 \%$ of the estimated GDP.

In the same period 12 Croatian state bonds have been admitted on foreign capital markets and their total nominal value was 4.94 billion Euros.

All bonds are denominated in Euros, except one which is denominated in Japanese Yens (Croatian National Bank, Annual Report 2004 - working version: 69-74).

\subsection{Financial Institutions in the Segment of Capital Business}

On the Croatian capital market there are brokerage houses (26); stock exchanges (2); banks authorized to deal with securities (16); pension companies (4); voluntary pension funds (6); closed voluntary pension funds (9) and pension insurance company (1).

\section{Pension Insurance}

Croatia as a transition state has been confronted with the necessity of coordination of a larger part of its financial system with the achievements of the free market and with the standards in the European Union, regarding its commitment to becoming a member of this association.

A special segment within this process of adjustment is the reform of the pension insurance which was until 2002 based on generational solidarity.

Pension insurance resulting from the pension reform in Croatia is turning into an exceptionally rapidly growing capital market. This appearance fact will have important influence on the trends in the entire financial sector; therefore special attention will have to be paid to this segment in the future.

\section{Limitations in Capital Transactions}

Following the Agreement about Stabilization and Accession, which Croatia has signed with the EU (it entered into force in 2005), and its particular provisions, i.e. based on the coordination of Croatian legislature with the Acquis Communautaire of the EU, it became possible to gradually liberalize some capital business transactions. 
When it joins the EU, Croatia will have to completely repeal all limitations relating to capital transactions.

\section{Conclusion}

As a state in transition, Croatia is facing the necessity of implementation of a series of reforms of its economic and financial system.

Globalization and integration processes additionally emphasize this requirement.

Inheritance, tradition as well as, to some extent, habits condition certain behavior and expectations hamper the development of the capital market.

The reached level of development of the capital market in Croatia is the result and the consequence of the openness of Croatian economy, but it is also, partly, the result of actual needs connected with the efficiency of this segment of the financial system.

Legal regulation of this area, which is to a great extent harmonized with the Acquis Communautaire of the EU, can and should additionally provide new breaks through, both in the development of the capital market and on the institutional plan.

The changes to date in the segment of capital transactions in Croatia indicate a marked sensitivity of the capital market. Positive development of the relations between Croatia and the EU invigorates this market, and prolongation of the settled activities results in negative changes in capital transactions.

It can therefore be realistically expected that the opening of negotiations about the membership in the EU will result in significant improvement in the development of the capital market in Croatia.

\section{Literature}

1. Novak, Branko (1999) Financijska tržišta i institucije, Osijek, Ekonomski fakultet u Osijeku (Financial Markets and Institutions, Osijek, Faculty of Economics in Osijek)

2. Hrvatska narodna banka, godišnje izvješće 2004 - radna verzija (Croatian National Bank, Annual Report for 2004 - working version) 